ENTITA : Jurnal Pendidikan Ilmu Pengetahuan Sosial dan Ilmu-Ilmu Sosial
http://ejournal.stainpamekasan.ac.id/index.php/entita
P-ISSN:2715-7555 E-ISSN:2716-1226

\title{
Respons Guru dalam Menumbuhkan Nilai Mandiri melalui Pembelajaran IPS selama Masa Adaptasi Kebiasaan Baru Covid-19 di Jawa Timur
}

\author{
Ahmad Tanfidzi Dahma Putra \\ Jurusan Pendidikan IImu Pengetahuan, Fakultas Pascasarjana, Univesitas Negeri Surabaya \\ amarendradharma99@gmail.com \\ Harmanto, Aminuddin Kasdi \\ Jurusan Pendidikan IImu Pengetahuan, Fakultas Pascasarjana, Univesitas Negeri Surabaya
}

\begin{abstract}
The implementation of character education in Indonesia is deemed not optimal, because it has not fully implemented character values to its full potential. The Indonesian government through Presidential Regulation Number 87 in 2017 launched the Strengthening Character Education program in all education units covering nationalist, independent, religious, integrity, and mutual cooperation. The purpose of this study was to document the teacher's response in independent values as one of the values in strengthening character education through social studies learning during the adaption of Covid-19 period. Participants included 19 randomized social studies teachers in East Java. This research is a descriptive study with an instrument form list of interviews. Data in the form of teacher responses were analyzed descriptively. The results showed that $84.2 \%$ of teachers had facilitated the growth of independent values in students who were written in the Long Distance Learning Implementation and $52.6 \%$ of teachers said that distance learning social studies was less effective, so there needed to be an interesting method for distance learning social studies so the learning become more effective.

Keywords: teacher response, independent, character education, social studies learning, Covid19.
\end{abstract}

\begin{abstract}
Abstrak
Pelaksanaan pendidikan karakter di Indonesia dirasa belum optimal, karena belum sepenuhnya mengimplementasikan nilai-nilai karakter secara maksimal. Pemerintah Indonesia melalui Peraturan Presiden Nomor 87 Tahun 2017 mencanangkan program Penguatan Pendidikan Karakter (PPK) di seluruh satuan pendidikan meliputi nilai nasionalis, mandiri, religius, integritas, serta gotong-royong. Tujuan penelitian ini adalah mendokumentasikan respons guru dalam menumbuhkan nilai mandiri sebagai salah satu nilai dalam penguatan pendidikan karakter melalui pembelajaran IPS pada masa Adaptasi Kebiasaan Baru Covid-19. Partisipan mencakup 19 guru IPS SMP secara acak di Jawa Timur. Penelitian ini merupakan penelitian deskriptif dengan instrumen berupa daftar wawancara. Data berupa respons guru dianalisis secara deskriptif. Hasil penelitian menunjukkan bahwa $84,2 \%$ guru telah memfasilitasi tumbuhnya nilai mandiri pada peserta didik yang tertulis dalam Rencana Pelaksanaan Pembelajaran (RPP) jarak jauh dan 52,6\% guru menyebutkan bahwa pembelajaran IPS jarak jauh kurang efektif dilaksanakan sehingga perlu adanya metode yang menarik dalam pembelajaran IPS jarak jauh agar pembelajarannya lebih efektif.
\end{abstract}

Kata Kunci: respons guru, mandiri, pendidikan karakter, pembelajaran IPS, Covid-19

Received : 14 Oktober 2020; Revised: 16 Desember 2020; Accepted: 18 Desember 2020 


\section{Pendahuluan}

Berdasarkan hasil penelitian Harvard University Amerika Serikat menuliskan bahwa kesusksesan hidup setiap orang tidak sebatas hanya ditentukan oleh pengetahuan serta kemampuan teknis (hard skil) yang didapatkan melalui pendidikan, tetapi lebih pada kemampuan mengelola diri yang didalamnya termasuk karakter atau soft skill (Akbar, 2000). Karakter atau soft skill seseorang menjadi bekal dirinya untuk mampu mengelola sikap dan kehidupannya dalam bersosial serta bermasyarakat. Hal tersebut mengindikasikan bahwa pengembangan pendidikan karakter pada peserta didik sangat penting untuk dilakukan.

Salah satu polemik dalam bidang pendidikan di berbagai negara adalah tentang pendidikan karakter, tidak terkecuali Indonesia. Pro dan kontra telah mewarnai diskursus berkaitan dengan proses penerapan pendidikan karakter. Pendidikan karakter merupakan suatu komponen yang esensial dari bagian tugas sekolah, namun masih banyak dari lembaga pendidikan yang kurang memperhatikan. Akibat dari kurangnya perhatian terhadap pendidikan karakter di lembaga pendidikan tersebut telah menyebabkan timbulnya beragam penyakit sosial di tengah masyarakat seperti rusaknya moral, akhlak, serta etika (Lickona, 2013).

Tujuan pendidikan nasional di Indonesia belum dapat dikatakan sepenuhnya tercapai. Hal tersebut terlihat dari orientasi lulusan yang lebih menekankan pada nilai-nilai materialistik, sekuler, pragmatis, hedonistik, rasionalistik namun kurang memiliki kecerdasan emosional. Kenyataan tersebut menyebabkan mutu lulusan belum sepenuhnya memenuhi karakter dalam tujuan pendidikan nasional yang mentargetkan keseimbangan kompetensi peserta didik meliputi aspek spiritual, emosional (moral), serta intelektual. Lembaga pendidikan tidak hanya berkewajiban dalam meningkatkan aspek akademis, lebih dari hal tersebut lembaga pendidikan juga bertanggungjawab atas pembentukan karakter peserta didik (Zubaiedi, 2011). Hal tersebut merupakan dua misi integral yang harus mendapatkan perhatian lembaga pendidikan. Disisi lain tuntutan dari aspek ekonomi dan politik pendidikan menyebabkan penekanan pada aspek akademis lebih dominan mengalahkan idealitas lembaga pendidikan dalam pembentukan karakter.

Persoalan berkaitan dengan karakter peserta didik telah menjadi pembahasan bersama di banyak pihak, oleh karena dapat dikatakan saat ini Indonesia sedang mengalami krisis karakter. Krisis tersebut ditandai dengan maraknya tindakan kriminalitas 
yang melibatkan peserta didik atau pelajar seperti meningkatnya pergaulan bebas, tawuran antar pelajar, pelecehan seksual, maraknya angka kekerasan anak ataupun remaja, aksi begal maupun geng motor yang menjurus pada tindakan kekerasan, merajalelanya kasus korupsi yang tidak hanya pada sektor pemerintahan namun juga pada berbagai sektor kehidupan masyarakat, serta puncaknya adalah adanya tindakan mengancam nyawa atau bahkan pembunuhan (Wibowo, 2013). Adanya fenomena tersebut menjadi catatan hitam dalam dunia pendidikan khususnya terkait citra pelajar dan lembaga pendidikan. Menanggapi kondisi tersebut semua pihak sepakat terhadap penanganan kemerosotan moral yang melibatkan peserta didik yaitu melalui pendekatan dimensi karakter. Persoalan karakter atau moral telah menjadi perhatian oleh lembaga pendidikan sejak lama. Tetapi adanya fenomena berkaitan dengan banyaknya kriminalitas yang melibatkan peserta didik atau pelajar menunjukkan bahwa masih terdapat kekurangan dari lembaga pendidikan dalam menumbuhkan manusia Indonesia yang berkarakter dan berakhlak mulia.

Pelaksanaan pendidikan karakter di Indonesia dirasa belum optimal, karena belum sepenuhnya mengimplementasi nilai-nilai karakter secara maksimal. Hal tersebut disebabkan oleh materi pembelajaran terutama yang berkaitan mengenai moral (karakter) cenderung terfokus pada aspek kognitif saja, sementara penekanan terhadap aspek afeksi maupun psikomotorik dirasa masih kurang. Adanya fenomena terkait krisis moral yang melibatkan peserta didik atau pelajar menjadi catatan bagi para guru untuk terus memberikan perhatian dan penekanan terhadap implementasi nilai-nilai pendidikan karakter. Melalui nilai-nilai karakter yang masuk di dalam proses pembelajaran diharapkan dapat menghasilkan peserta didik yang memiliki karakter kuat dan tangguh serta mampu menghadapi beragam tantangan pembangunan. Karakter bisa dibentuk maupun dikondisikan oleh seseorang, baik guru di lingkungan sekolah maupun orang tua di lingkungan keluarga (Ahmadi, 2017). Guru dan orang tua mempunyai peran vital dalam proses pembentukan karakter pada anak (Wuladari \& Kristiawan, 2017).

Pembangunan karakter memiliki urgensi luas serta sifatnya yang multidimensional. Luas dikarenakan memiliki kaitan dengan proses pengembangan berbagai aspek (multiaspek) potensi-potensi keunggulan yang bersifat multidimensional. Oleh sebab itu, dapat juga dituliskan bahwa: 1) Karakter adalah suatu hal yang sangat esensial dalam kehidupan berbangsa dan bernegara, karena hilangnya karakter berakibat pada hancurnya moral generasi penerus bangsa, 2) Karakter memiliki peran sebagai "kemudi" serta kekuatan bangsa sehingga tidak goyah dan terombang-ambing dalam proses 
mencapai tujuan bangsa, 3) Karakter bukanlah sesuatu yang datang dengan sendirinya, melainkan perlu dibentuk dan dibangun agar terbentuk suatu bangsa yang memiliki martabat tinggi di mata Internasional. Tiga tatanan dasar pada pembangunan karakter bangsa, yaitu: 1) Meningkatkan serta menguatkan jati diri bangsa di setiap masyarakat, 2) Selalu menjaga keutuhan Negara Kesatuan Indonesia (NKRI), dan 3) Membentuk akhlak yang mulia dan berperikemanusiaan yang tinggi pada seluruh masyarakat Indonesia (Megawangi, 2007).

Pemerintah Indonesia melalui Peraturan Presiden Nomor 87 Tahun 2017 mencanangkan program Penguatan Pendidikan Karakter (PPK) di seluruh satuan pendidikan. Program Penguatan Pendidikan Karakter (PPK) di Indonesia merupakan suatu program atau gerakan yang dilaksanakan di lembaga pendidikan untuk meningkatkan karakter peserta didik melalui proses perumusan, tranformasi, tranmisi, serta pengembangan potensi sesuai dengan falsafah hidup Pancasila dengan cara kombinasi olah hati (etik dan spiritual), olah rasa (estetik), olah pikir (literasi dan numerasi), dan olah raga (kinestetik). Penguatan Pendidikan Karakter (PPK) yang perlu diterapkan di masing-masing satuan pendidikan merujuk pada nilai utama yang berjumlah lima, meliputi nilai nasionalis, mandiri, religius, integritas, serta gotong-royong. Menurut Asmani (2011) tujuan pendidikan karakter mandiri adalah penanaman nilai-nilai kemandirian serta terbentuknya proses pembaruan tata kehidupan bersama dengan lebih menghargai kebebasan individu pada masing-masing peserta didik.

Pandemi Corona Virus Disease (Covid-19) merupakan penyakit menular infeksi saluran pernafasan yang disebabkan oleh virus. Sebanyak 213 negara di dunia telah mengalami pandemi Covid-19 selama tahun 2020 (World Health Organization, 2020). Indonesia merupakan salah satu negara yang mengalami pandemi Covid-19 dan masih terus berlangsung hingga sekarang. Dalam upaya menanggulangi penyebaran Covid-19, pemerintah menganjurkan adanya pembatasan sosial (physical distancing) untuk saling menjaga jarak antara satu sama lain serta menghindari kerumunan. Salah satu realisasi pembatasan sosial yang dilakukan oleh pemerintah adalah dengan menutup sekolah dan melakukan pembelajaran jarak jauh bagi seluruh jenjang pendidikan baik pendidikan dasar, menengah, atas hingga perguruan tinggi (Tim Kerja Kementerian Dalam Negeri, 2020).

Penguatan pendidikan karakter dalam masa pandemi Covid-19 (Corona Virus Disease) menjadi tantangan tersendiri bagi masing-masing satuan pendidikan. Masingmasing sekolah menekankan pemberian instruksi akademis secara jarak jauh. Meskipun 172 
diskusi semacam itu tidak dapat mendukung seluruh siswa, karena ada siswa yang bergantung kepada pembelajaran tatap muka dan adanya interaksi langsung dengan guru (Phelps \& Sperry, 2020). Pasalnya segala aktivitas mengalami pembatasan untuk mengurangi transmisi penyebaran virus, salah satunya dalam bidang pendidikan. Satuan pendidikan diharuskan untuk melaksanakan pembelajaran jarak jauh atau biasa disebut $e$ learning. Menurut Khan dalam Surjono (2013) menuliskan bahwa e-learning merunjuk pada proses transfer materi serta pelaksanaan kegiatan belajar mengajar kepada siapapun, dimanapun, dan kapanpun tanpa terbatas ruang serta waktu dengan menggunakan teknologi komunikasi sehingga pembelajaran bersifat terbuka, fleksibel, dan terdistribusi.

Salah satu pembelajaran wajib di satuan pendidikan Sekolah Menengah Pertama (SMP) adalah mata pelajaran IImu Pengetahuan Sosial (IPS). Mata pelajaran IPS disusun secara terpadu, sistematis, dan komprehensif sebagaimana yang tertulis dalam Peraturan Kementerian Pendidikan Nasional Nomor 22 Tahun 2006. Kegiatan belajar mengajar IPS bertujuan agar peserta didik mampu mendapatkan pengetahuan secara luas dan mendalam pada bermacam-macam ilmu sosial yang ada. Pembelajaran IPS dirancang untuk mampu menjadikan peserta didik agar menjadi insan yang berbudi luhur (Rosardi \& Zuchdi, 2014). Pembelajaran IPS sangat banyak berperan dalam mewujudkan karakteristik siswa berlandaskan moral yang baik dan dapat dijadikan acuan untuk bersosialisasi dalam kehidupan sehari-hari sebagai makhluk sosial.

Pembelajaran IPS merupakan integrasi berbagai cabang ilmu, yakni sejarah, geografi, ekonomi, hukum dan politik, serta sosiologi/anropologi. Disiplin ilmu IPS mempunyai keterpaduan yang tinggi karena sejarah memberikan wawasan tentang peristiwa-peristiwa yang terjadi pada masa lampau, geografi memberikan wawasan tentang kondisi dan wilayah-wilayah di bumi, ekonomi memberikan wawasan tentang berbagai macam kebutuhan manusia, hukum dan politik memberikan wawasan terkait peraturan-peraturan dalam hidup bermasyarakat, berbangsa dan bernegara, serta sosiologi/antropologi memberikan wawasan yang berkenaan dengan nilai-nilai, kepercayaan, struktur sosial dan sebagainya (Anshori, 2014). Pembelajaran IPS merupakan pembelajaran yang sangat cocok dalam penerapan pendidikan karakter, salah satunya karakter mandiri. Penerapan karakter dalam pembelajaran IPS diharapkan dapat menciptakan karakter unggul yang bernilai luhur, berbangsa, dan beragama.

Berdasarkan kajian di atas, penulis ingin mendokumentasikan respons guru dalam menumbuhkan nilai mandiri sebagai salah satu nilai dalam penguatan pendidikan karakter 
melalui pembelajaran IPS pada masa Adaptasi Kebiasaan Baru (AKB) Covid-19 serta solusi dari kendala yang dihadapi dalam kegiatan pembelajaran

\section{Metode Penelitian}

Penelitian ini merupakan penelitian deskriptif berdasarkan hasil data respons guru dalam menumbuhkan nilai mandiri pada pembelajaran IPS selama masa Adaptasi Kebiasaan Baru (AKB) Covid-19. Partisipan mencakup 19 guru IPS dari berbagai Sekolah Menengah Pertama di Jawa Timur.

Teknik pengambilan data penelitian dengan wawancara dan dokumentasi. Instrumen penelitian untuk respons guru berupa daftar pertanyaan wawancara untuk mengetahui respons guru dan kemungkinan penyelesaian permasalahan dalam pembelajaran IPS selama masa Adaptasi Kebiasaan Baru Covid-19. Dalam melakukan analisis data, peneliti menggunakan tiga cara analisis yang dilakukan dalam waktu yang bersamaan, yakni proses reduksi data, penyajian hasil data, serta penarikan kesimpulan atau verifikasi (Miles \& Huberman, 1992) yang dapat dilihat pada Gambar 1.

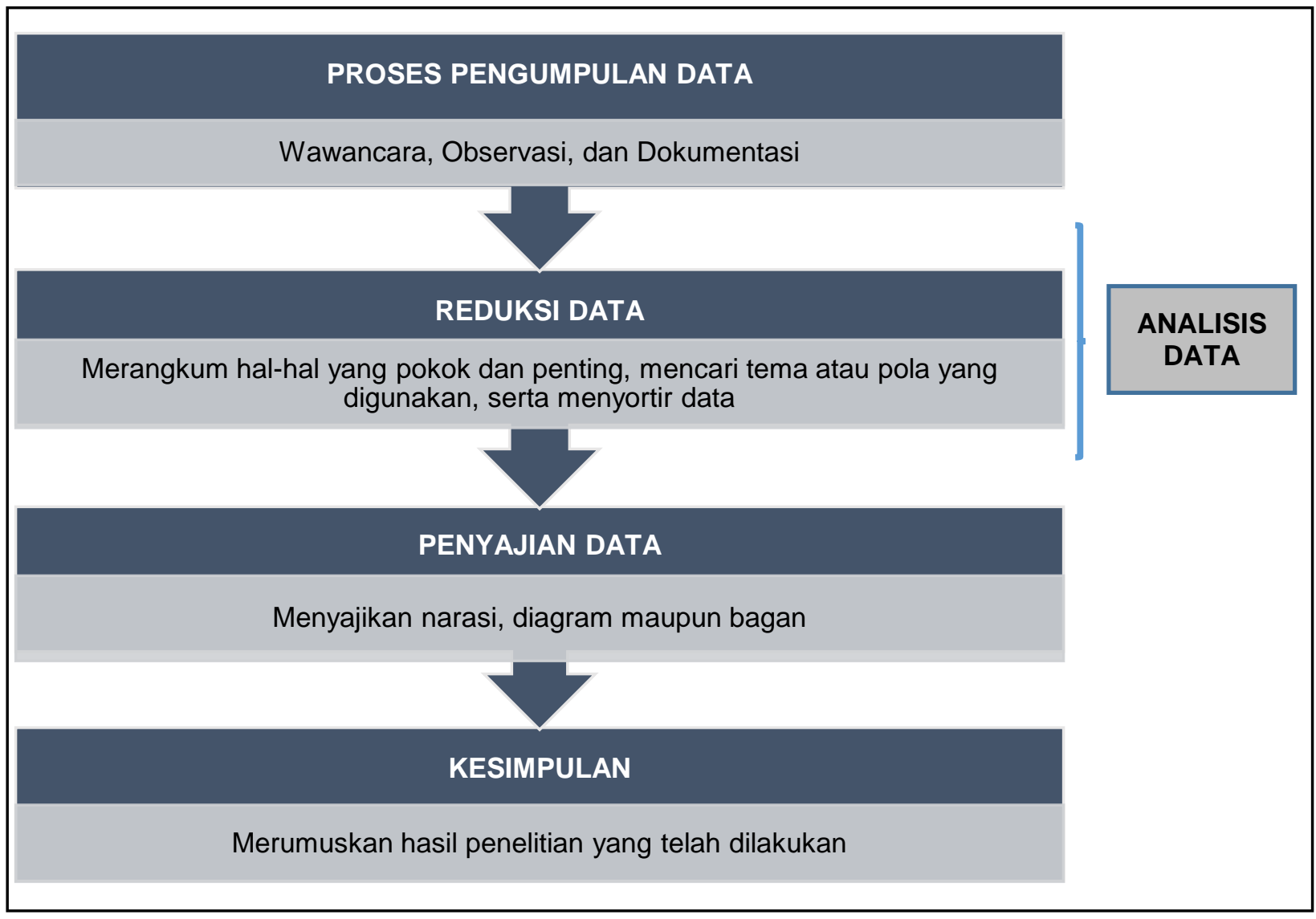

Gambar 1. Komponen-komponen Analisis Data 


\section{Hasil dan Pembahasan}

\section{a. Demografi Partisipan}

Partisipan dalam penelitian ini terdiri dari 19 guru mata pelajaran IImu Pengetahuan Sosial (IPS) SMP di Jawa Timur. Guru terdiri dari 10 laki-laki dan 9 perempuan. Partisipan guru didominasi oleh usia $>50$ tahun dengan persentase 37\%, diikuti oleh partisipan usia 40-50 tahun dengan persentase $31 \%$, serta usia $20-30$ dan 30-40 tahun memiliki persentase yang sama yakni 16\%. Rentang usia guru dapat dilihat pada Gambar 2.

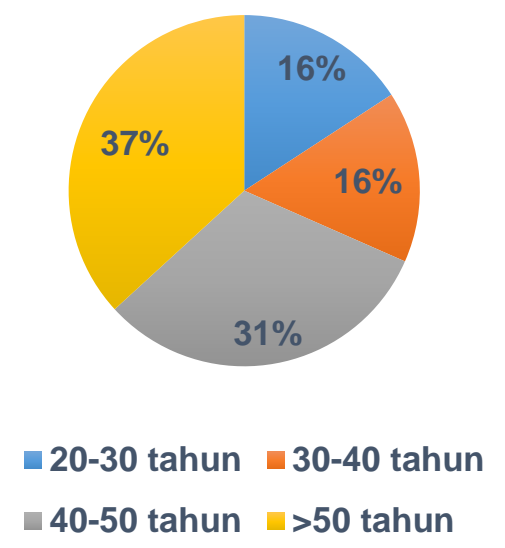

Gambar 2. Rentang Usia Partisipan Guru ( $n=19)$

Guru dengan pengalaman mengajar >15 tahun memiliki jumlah terbanyak dengan persentase sebesar $74 \%$ yang mengindikasikan bahwa guru telah memiliki berbagai pengalaman mengajar. Guru yang mengajar $<5$ tahun memiliki persentase 16\%, sedangkan guru dengan pengalaman mengajar 5-10 tahun dan 10-15 tahun masingmasing memiliki persentase 5\%. Pengalaman mengajar dalam kisaran tahun dapat dilihat pada Gambar 3.

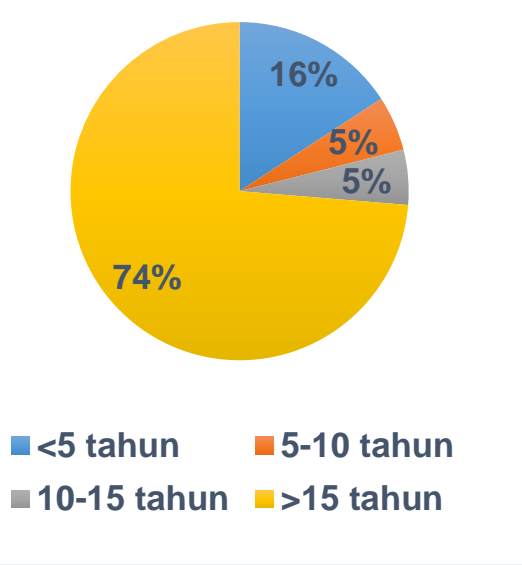

Gambar 3. Pengalaman Mengajar Guru $(n=19)$ 


\section{b. Analisis Tugas dalam Pembelajaran IPS selama Masa Adaptasi Kebiasaan Baru (AKB) Covid-19}

Dalam proses pembelajaran, sikap peserta didik atau karakter peserta didik sangat mempengaruhi hasil belajar peserta didik. Hal ini menunjukkan bahwa karakter sangat berpengaruh besar terhadap peserta didik. Pada abad ke-21, dunia pendidikan mulai beralih dari pendidikan berbasis nilai menjadi pendidikan berbasis karakter. Adanya penurunan nilai moralitas, ketidakadilan yang merajalela, dan tingkat solidaritas yang rendah telah mewabah dalam dunia pendidikan (Kardiyem, 2013). Karakter merupakan pembentuk sikap dan perilaku seseorang dalam bertindak. Karakter mencerminkan bagaimana orang tersebut menjalani kehidupan sehari-hari. Karakter seseorang muncul apabila terjadi interaksi dalam sebuah entitas sosial, baik pada masyarakat perkotaan maupun masyarakat pedesaan.

Selama masa pandemi Covid-19 terjadi, masing-masing satuan pendidikan melaksanakan pembelajaran jarak jauh. Pembelajaran yang mulanya dilaksanakan langsung secara tatap muka di kelas kemudian dialihkan menjadi Pembelajaran Jarak Jauh (PJJ) atau Dalam Jaringan (Daring)/Online. Guru sebagai pendidik memiliki peran yang sangat penting dalam keberlangsungan pembelajaran utamanya dalam hal pembentukan karakter peserta didik selama pembelajaran online.

Pendidikan karakter merupakan pembelajaran dengan berbagai aspek pembentukan sikap, sehingga pendidikan bukan hanya sekedar mengajarkan pengetahuan melainkan disertai dengan proses implementasi nilai-nilai positif yang mampu membentuk karakter peserta didik. Pemerintah telah mengidentifikasi delapan belas nilai yang sesuai dengan ajaran kepercayaan, sosial-budaya, falsafah negara, dan tujuan dari pendidikan nasional, yakni : 1) Religius, 2) Jujur, 3) Toleransi, 4) Disiplin, 5) Bekerja keras, 6) Kreatif, 7) Mandiri, 8) Demokrasi, 9) Rasa ingin tahu, 10) Semangat kebangsaan, 11) Cinta tanah air, 12) Menghargai prestasi, 13) Komunikatif/bersahabat, 14) Cinta damai, 15) Gemar membaca, 16) Peduli lingkungan, 17) Peduli sesama (sosial), dan 18) Bertanggung jawab (Permendikbud, 2018).

Salah satu sikap yang mendukung terbentuknya karakter yang baik pada peserta didik adalah sikap mandiri. Sikap mandiri merupakan perilaku yang tidak bergantung pada orang lain dan mampu mempergunakan segala tenaga, pikiran, dan waktu pribadi untuk merealisasikan mimpi, harapan, serta cita-cita. Seseorang yang mempunyai sikap mandiri pasti memiliki etos kerja yang tinggi (pekerja keras), daya juangnya tinggi, berani, tangguh tahan banting, professional, kreatif, dan menjadi pembelajar sepanjang 176 
hayat (Kusnoto, 2017). Kemandirian adalah nilai yang tertanam dalam setiap kegiatan, "Siapa yang menanam dan merawatnya pasti akan menuai hasilnya", maka setiap kegiatan yang dilakukan dengan kemandirian dan kesungguh-sungguhan pasti akan menghasilkan sesuatu yang baik.

Berdasarkan data yang diperoleh dapat diketahui bahwa sebanyak 84,2\% guru telah memfasilitasi tumbuhanya nilai mandiri pada peserta didik yang tertulis dalam Rencana Pelaksanaan Pembelajaran (RPP) jarak jauh, sedangkan sisanya sebanyak $15,8 \%$ guru belum memfasilitasi pembentukan sikap mandiri tersebut. Perlunya pembentukan karakter mandiri pada peserta didik adalah agar peserta didik mampu dan terbiasa melakukan hal-hal dengan usahanya sendiri sehingga terbentuk insan yang mampu bertanggung jawab terhadap dirinya sendiri, masyarakat maupun bangsa dan negara.

Karakter seseorang berkembang berdasarkan potensi dari bawaan lahir atau lebih sering dikenal sebagai karakter biologis dan akan mengalami aktualisasi ketika berinteraksi dengan lingkungannya (Zubaedi, 2012). Karakter dapat dibentuk dan diaktualisasikan melalui pendidikan, hal tersebut dikarenakan pendidikan merupakan alat yang paling efektif untuk menyadarkan individu pada jati diri kemanusiannya. Oleh karena itu penting untuk membentuk karakter peserta didik dalam pembelajaran di sekolah, salah satunya melalui pembelajaran IPS.

\section{c. Efektifitas Pembelajaran IPS Jarak Jauh}

Dalam skala penilaian 1-4 dengan kriteria 1: tidak efektif, 2: kurang efektif, 3: efektif, dan 4: sangat efektif menunjukkan bahwa sebanyak 52,6\% guru menyebutkan bahwa pembelajaran IPS jarak jauh atau online kurang efektif dilaksanakan, khususnya dalam pembentukan karakter mandiri pada peserta didik. Sebaliknya, sebanyak 47,4\% berpendapat bahwa pembelajaran IPS jarak jauh tetap efektif dilaksanakan bahkan dalam konteks pembentukan karakter mandiri pada peserta didik. Karakter mandiri merupakan suatu sikap atau tindakan untuk menyelesaikan sesuatu dengan tidak bergantung kepada orang lain (Permendikbud, 2018). Karakter mandiri merupakan salah satu cakupan dalam pembentukan karakter peserta didik berdasarkan Peraturan Presiden Nomor 87 Tahun 2017 tentang program Penguatan Pendidikan Karakter (PPK) di seluruh satuan pendidikan.

Pendidikan karakter bertujuan untuk membentuk figur manusia Indonesia yang memiliki sifat berkarakter, inovatif, suka bekerja keras, mampu bertanggung jawab, percaya diri, mempunyai jiwa kepemimpinan, tidak mudah terjerumus ke dalam perilaku 
yang menyimpang. Secara spesifik pedidikan karakter memiliki tiga tujuan utama sesuai yang tercantum dalam grand design pendidikan karakter, yakni:

1) Perumusan dan peningkatan potensi. Pendidikan karakter perlu untuk dirumuskan dan diimplementasikan hingga dapat meningkatkan potensi peserta didik dan seluruh masyarakat sehingga mempunyai kepribadian, perilaku, kebiasaan, dan hakikat bermasyarakat sesuai dengan sikap Pancasila.

2) Perbaikan dan penguatan. Pendidikan karakter memiliki tujuan untuk memperbaiki karakter peserta didik dan warga masyarakat dengan cara memperkuat peran anggota keluarga, sekolah, komunitas, khalayak ramai, dan pemerintah untuk turut serta berperan aktif dalam mengembangankan potensi warga negara Indonesia menuju bangsa yang berkarakter.

3) Penyaring. Pendidikan karakter bertujuan untuk menyaring dan memilah nilai-nilai dalam masyarakat di Indonesia maupun masyarakat dunia agar terbentuk bangsa dan negara yang lebih maju dan bermartabat (Saridjo, 2011).

Dengan demikian, pendidikan karakter mempunyai tujuan untuk membentuk individu agar mampu berakhlak mulia, berkarakter, berkepribadian, berilmu, mandiri, disiplin, dan menjadi warga negara yang berjiwa pemimpin serta bertanggung jawab. Sehingga efektifitas pembelajaran IPS dalam membentuk karakter mandiri pada peserta didik sangat diperlukan agar peserta didik mampu menjadi individu yang berkarakter baik.

Dalam pembelajaran jarak jauh, guru berusaha mewujudkan terciptanya karakter yang baik pada siswa melalui penugasan. Keberhasilan pendidikan IPS yang dipandang berhasil di kalangan masyarakat dapat membentuk perilaku siswanya dalam sopan santun, dapat bergaul, bisa menempatkan sesuatu pada tempatnya, serta dapat membedakan antara baik dan buruk dalam perbuatan sehari-hari.

Berdasarkan Surat Edaran Mendikbud No. 4 Tahun 2020 tentang Pelaksanaan Kebijakan Pendidikan dalam Masa Darurat Penyebaran Coronavirus Disease (Covid2019). Poin dua surat edaran tersebut menuliskan terkait bagaimana seharusnya proses belajar jarak jauh dilakukan. Berikut penjelasannya secara detail:

1) Pertama, pembelajaran dilaksanakan untuk memberikan pengalaman belajar yang bermakna bagi siswa sehingga siswa memperoleh pengalaman baru dalam setiap pembelajaran tanpa terbebani tuntutan menuntaskan seluruh capaian kurikulum untuk kenaikan kelas maupun kelulusan. 
2) Kedua, difokuskan pada pendidikan kecakapan hidup, antara lain mengenai pandemi Covid-19. Siswa diharapkan mampu mengetahui apa itu Covid-19, bagaimana cara meminimalisir penyebarannya, gejala-gejala yang dialami ketika tertular virus, serta bagaimana upaya dan penaggulangannya ketika terinfeksi atau berdekatan dengan orang yang terinfeksi. Dengan mengetahui hal-hal seperti itu, diharapkan siswa memiliki kecakapan hidup yang baik guna mampu menyelesaikan setiap pembelajaran dengan baik secara jarak jauh. Proses tersebut untuk membentuk kesehatan mental siswa secara jarak jauh.

3) Ketiga, aktivitas dan tugas pembelajaran dapat bervariasi antarsiswa, sesuai minat dan kondisi masing-masing, termasuk mempertimbangkan kesenjangan akses/ fasilitas belajar di rumah. Hal tersebut dilakukan Karena tidak semua siswa memiliki akses yang sama dalam hal fasilitas pembelajaran jarak jauh. Sehingga guru dituntut untuk mampu mengembangkan pembelajaran secara fleksibel tergantung dengan kondisi yang ada.

4) Keempat, bukti atau produk aktivitas belajar dari rumah diberi umpan balik yang bersifat kualitatif dan berguna dari guru, tanpa diharuskan memberi skor/nilai kuantitatif. Adanya pemberian feedback secara langsung baik itu lisan ataupun tulisan akan memberikan dampak yang baik untuk siswa. Siswa menjadi senang dan merasa dihargai karena setiap usaha yang digunakan untuk mengerjakan penugasan mendapatkan respon dari guru (Arifa, 2020).

Pada pembelajaran tatap muka guru lebih leluasa menyampaikan materi ajar dan mampu menilai motivasi belajar para peserta didik. Di masa pandemi Covid-19 guru diharapkan dapat lebih kreatif dan inovatif untuk membuat bahan ajar yang menarik minat dan semangat belajar peserta didik, selain itu guru juga dituntut untuk cermat dalam penguasaan ilmu pengetahuan dan teknologi (Syaharuddin \& Mutiani, 2020). Peran guru sangat vital dalam kegiatan pembelajaran jarak jauh. Oleh karena itu guru mempunyai kewenangan untuk berkomunikasi dengan orang tua atau wali siswa dalam hal kordinasi pembelajaran. Akan lebih baik bila komunikasi guru dengan wali siswa berjalan lancar. Hal tersebut dapat meningkatkan kualitas pembelajaran IPS yang berlangsung karena wali siswa memiliki peran penting sebagai pembimbing sekaligus motivator bagi anak-anaknya saat sedang melangsungkan pembelajaran online di rumah. 


\section{d. Analisis Kendala Pembelajaran IPS Jarak Jauh}

Pembelajaran jarak jauh selama masa Adaptasi Kebiasaan Baru (AKB) Covid-19 membawa perubahan dalam dunia pendidikan. Sebanyak $94,7 \%$ guru berpendapat bahwa terdapat terdapat kendala dalam pembelajaran IPS jarak jauh terutama dalam menumbuhan nilai mandiri pada peserta didik. Kendala tersebut antara lain dapat ditulis dalam Tabel 1.

Tabel 1. Kendala Pembelajaran IPS Jarak Jauh dalam Menumbuhkan Nilai Mandiri pada Peserta didik

\section{Daftar Kendala Pembelajaran IPS Jarak Jauh}

1. Peserta didik yang tidak memiliki smartphone dan koneksi internet kesulitan untuk menyelesaikan tugas yang diberikan guru

2. Guru tidak mengetahui apakah tugas tersebut dikerjakan secara mandiri atau dikerjakan oleh orang lain

3. Jawaban antar peserta didik sama

4. Guru tidak bisa mengontrol secara langsung tingkat kemandirian masing-masing peserta didik sebagai efek hasil pembelajaran

5. Maksimal hanya $50 \%$ anak yang benar-benar aktif terlibat pembelajaran jarak jauh

6. Dalam satu kelas selalu ada peserta didik yang tidak mengumpulkan tugasnya bahkan melewati tenggat waktu yang diberikan

7. Peserta didik yang terbiasa diarahkan dan dibimbing guru secara langsung sering terlambat mengumpulkan tugas

8. Peserta didik kurang memahami materi yang diberikan secara online

Untuk meminimalisir kendala dalam meningkatkan nilai mandiri melalui pembelajaran IPS jarak jauh, beberapa guru memiliki solusi dan saran. Saran guru dalam pelaksanaan pembelajaran IPS jarak jauh agar menjadi pembelajaran yang efektif dapat dilihat pada Tabel 2.

Tabel 2. Saran Guru untuk Meminimalisir Kendala dalam Meningkatkan Nilai Mandiri pada Peserta didik melalui Pembelajaran IPS Jarak Jauh

\footnotetext{
Daftar Saran Guru untuk Meminimalisir Kendala Pembelajaran IPS Jarak Jauh

1. Salah satu metode mendidik adalah membiasakan. Jadi untuk menanamkan nilai mandiri hendaknya terus dibiasakan untuk menjalankan atau menerapkan nilai-nilai kemandirian ketika pembelajaran IPS berlangsung ataupun dalam penugasan

2. Tugas atau soal yang diberikan kepada peserta didik hendaknya bersifat kontekstual terutama hal-hal yang ada di sekitar tempat tinggal peserta didik

3. Pada tugas diberikan unsur nilai karakter kejujuran dan memasukkan norma agama

4. Pemberian tugas yang berbeda pada masing-masing peserta didik sehingga meminimalisir kerja sama di antara peserta didik

5. Memberikan semangat, motivasi, dan menjalin komunikasi kepada peserta didik serta wali dari peserta didik

6. Pembelajaran sebaiknya dilangsungkan dengan aplikasi berbasis video call seperti zoom meeting, google meet, dan sejenisnya

7. Menyampaian materi yang menarik dan menantang sehingga timbul keinginan peserta didik untuk mengerjakan tugas dengan sendirinya

8. Kekompakan antara guru dan peserta didik diperlukan sehingga mampu mengontrol pembelajaran peserta didik dengan baik

9. Penilaian karakter mandiri dapat diukur dengan pemberian tugas berupa video buatan peserta didik dengan catatan cara pengukuran kapasitas video buatan peserta didik dan orang dewasa hendaknya guru paham
} 
Beberapa guru telah memiliki solusi untuk permasalahan ataupun kendala dalam proses pembelajaran IPS dalam meningkatkan karakter mandiri pada peserta didik. Sehingga dengan adanya solusi tersebut diharapkan tujuan pendidikan dapat tercapai. Tujuan pendidikan menurut Salim dan Kurniawan (2012) adalah suatu perubahan yang diinginkan dan diusahakan dalam kegiatan belajar mengajar, baik pada tingkah laku individu dalam kehidupan pribadinya maupun dalam lingkup masyarakat. Pendapat tersebut dapat dipahami bahwasanya tujuan pendidikan merupakan hasil akhir yang diinginkan atau diharapkan melalui proses pendidikan (Daradjat, 1996).

Menurut Djalil dan Megawangi (2006) hal-hal yang dapat dilakukan oleh guru dalam upaya implementasi pendidikan karakter adalah dengan:

1) Menerapkan metode pembelajaran yang melibatkan partisipasi aktif dari siswa

2) Menciptakan lingkungan belajar yang kondusif

3) Memberikan pendidikan karakter secara eksplisit, sistematis, dan berkesinambungan dengan melibatkan aspek knowing the good, loving the good, and acting the good.

4) Memperhatikan keunikan siswa masing-masing dalam menggunakan metode pembelajaran.

Pendidikan dan pembelajaran yang dilangsungkan selama pandemi Covid-19 tidak berbasis ruang kelas dan sekolah. Pembelajaran berlangsung secara universal yang tidak terjadi di lingkungan sekolah, melainkan lingkungan keluarga dan masyarakat. Bahkan seringkali proses belajar untuk hal-hal yang bersifat nilai (value) dan motivasi lebih banyak terjadi di keluarga dan masyarakat. Oleh karena itu lingkungan keluarga sebagai pusat tempat siswa berkembang dan belajar selama pandemi Covid-19 harus diupayakan menjadi wahana penumbuhan nilai-nilai yang positif dan memotivasi bagi peserta didik. Jika dikaitkan dengan aspek-aspek kecakapan hidup, maka pengembangan aspek kesadaran diri akan lebih efektif jika didukung oleh contoh perilaku sehari-hari yeng dapat diamati di lingkungan keluarga. Sehingga untuk meminimalisir kendala yang dihadapi dalam pembelajaran, orang tua sebagai guru di rumah memiliki peran yang sangat penting dalam membantu, mendukung dan memberikan contok kepada peserta didik. 


\section{Kesimpulan}

Berdasarkan penelitian yang telah dilakukan dapat diketahui bahwa:

1. Sebanyak $84,2 \%$ guru telah memfasilitasi tumbuhnya nilai mandiri pada peserta didik yang tertulis dalam Rencana Pelaksanaan Pembelajaran (RPP) jarak jauh.

2. Sebanyak $52,6 \%$ guru menyebutkan bahwa pembelajaran IPS jarak jauh kurang efektif dilaksanakan.

3. Perlu adanya metode yang menarik dalam pembelajaran IPS jarak jauh agar lebih efektif dilaksanakan dan mampu mengakomodir nilai mandiri pada peserta didik.

\section{Saran}

Penelitian ini menghasilkan data respons guru terkait efektivitas penerapan nilai mandiri melalui pembelajaran IPS online selama masa Adaptasi Kebiasaan Baru (AKB) Covid-19 dengan dibatasi pada sejumlah partisipan saja. Saran untuk penelitian selanjutnya mencakup lebih banyak partisipan pada regional yang berbeda sehingga data yang dihasilkan mampu merepresentasikan lebih rinci mengenai penerapan nilai mandiri dalam pembelajaran IPS jarak jauh.

\section{Referensi}

Ahmadi, F.Y. 2017. Pembelajaran Wacana sebagai Landasan dalam Berliterasi Sastra untuk Meningkatkan Karakter Siswa. Prosiding Seminar Nasional Bahasa dan Sastra (SENASBASA) Edisi 1.

Akbar, Ali Ibrahim. 2000. Tentang Pendidikan Karakter. Jakarta: Rajawali.

Anshori, S. 2014. Kontribusi IImu Pengetahuan Sosial dalam Pendidikan Karakter. Jurnal Edueksos, Vol. 3(2): 59-76.

Asmani, M.J. 2011. Buku Panduan Internalisasi Pendidikan Karakter di Sekolah. Yogyakarta: Diva Press.

Daradjat. Zakiyah. 1996. Metodologi Pengajaran Islam. Jakarta: Bumi Aksara.

Kardiyem. 2013. Internalisasi Pendidikan Karakter dalam Akuntansi (Inspirasi) Diary: Solusi Konservasi Moral. Jurnal Dinamika Akuntansi, Vol. 5(1): 47-54.

Kusnoto, Y. 2017. Internalisasi Nilai-Nilai Pendidikan Karakter pada Satuan Pendidikan. Sosial Horizon: Jurnal Pendidikan Sosial, Vol. 4(2): 247-256.

Lickona, Thomas. 2013. Educating for Character. Bandung: Nusamedia.

Megawangi, Ratna. 2007. Semua Berakar pada Karakter. Jakarta: Penerbit FE - UI. 
Miles, B. Mathew \& Huberman, A. Michael. 1992. Qualitative Data Analysis: A Sourcebook of New Methods. SAGE: Bevwrly Hills

Peraturan Kementerian Pendidikan dan Kebudayaan. 2018. Peraturan Presiden Nomor 87 tahun 2017 tentang Penguatan Pendidikan Karakter. Jakarta.

Phelps, C., \& Sperry, L.L. 2020. Dhildren and the Covid-19 Pandemic. Psychological Trauma: Theory, Research, Practice, and Policy, Vol. 12(1):73-75.

Rosardi, R.G. \& Zuchdi, D. 2014. Keefektifan Pembelajaran IPS dengan Strategi Pemecahan Masalah untuk Meningkatkan Karakter Kemandirian dan Kepedulian Siswa. Harmoni Sosial, Vol 1(2): 190-203.

Salim, Haitami. \& Kurniawan, Syamsul. 2012. Studi IImu Pendidikan Islam. Yogyakarta: Ar-Ruzz Media.

Saridjo, Marwan. 2011. Pendidikan Islam dari Masa ke Masa: Tinjauan Kebijakan Publik terhadap Pendidikan Islam di Indonesia. Jakarta: Yayasan Ngali Aksara.

Surjono, Herman Dwi. 2013. Membangun Course E-Learning Berbasis Moodle. Yogyakarta: UNY Press.

Tim Kerja Kementerian Dalam Negeri. 2020. Pedoman Umum Menghadapi Pandemi COVID-19 Bagi Pemerintah Daerah: Pencegahan, Pengendalian, Diagnosis dan Manajemen. Kementerian Dalam Negeri Republik Indonesia. Jakarta.

Wibowo. 2013. Perilaku dalam Organisasi. Jakarta: OT. Raja Grafindo Persada.

World Health Organization. 2020. Public Statement for Collaboration on Covid-19 Vaccins Development. News Room. World Health Organization. Diakses melalui: https://www.who.int/news-room/detail/.

Wulandari, Y. \& Kristiawan, M. 2017. Strategi Sekolah dalam Penguatan Pendidikan Karakter bagi Siswa dengan Memaksimalkan Peran Orang Tua. Jurnal Manajemen, Kepemimpinan, dan Supervisi Pendidikan, Vol. 2(2).

Zubaedi. 2012. Desain Pendidikan Karakter: Konsepsi dan Aplikasinya pada Lembaga Pendidikan. Jakarta: Kencana. 
Ahmad Tanfidzi Dahma Putra, Harmanto, Aminuddin Kasdi 